\title{
The Effects of COVID-19 Pandemic on the Economies of the Gulf Cooperation Council States due to Low Oil Prices
}

\author{
Khaled Abdalla Moh'd AL-Tamimi ${ }^{1}$ \\ ${ }^{1}$ Department of Financial and Administrative Sciences, Irbid University College, Al-Balqa' Applied University, \\ Jordan \\ Correspondence: Dr. Khaled Abdalla Moh'd AL-Tamimi, Associate Professor, Department of Financial and \\ Administrative Sciences, Irbid University College, Al-Balqa' Applied University, Jordan.
}

Received: June 26, 2020

Accepted: September 3, 2020

Online Published: January 1, 2021

doi:10.5430/ijfr.v12n1p279

URL: https://doi.org/10.5430/ijfr.v12n1p279

\begin{abstract}
This paper shows the effect of a drop in oil price on the economic growth of GCC states as a result of the Covid-19 pandemic using monthly data for (2019/2020 M1 - 2019/2020 M12) where oil price is an explanatory variable and economic growth is the affected variable. Because the economies of the GCC countries are centered mostly on oil, the spread of COVID-19 pandemic has become a serious concern since they depend on the outside world in diverse ways. The confirmed number of cases in the GCC countries is eliciting fear about security in these countries. This paper focuses on analyzing theoretical and empirical literature reviews to show the effects of oil price on economic growth and explaining this effect in GCC states for this period using the autoregressive distributed lag (ARDL) technique in Eviews program. This paper concluded that there are negative and significant effects of oil price on the economic growth of Kuwait and Qatar, but insignificant effects of oil price on the economic growth of Bahrain, Oman and the United Arab Emirates and a positive and significant effect of oil price on the economic growth of Saudi Arabia by using monthly data for (2019/2020 M1 - 2019/2020 M12) at a significance level of 5\%. Also, this paper reaches a recommendation of the GCC states to improve their economies through other sectors and not by relying on oil to enhance their economic growth.
\end{abstract}

Keywords: coronavirus, COVID-19 pandemic, oil prices, GCC states, economic growth, autoregressive distributed lag (ARDL)

\section{Introduction}

Coronavirus outbreak was first reported on 31 December 2019 in Wuhan, China. On 21 January 2020, more than 100,000 cases of coronavirus were reported in 100 states around the globe. Coronavirus has negative effects on the total demand and thus volatile prices of food in the short run and decreasing tourists and workers' mobility (Albulescu, 2020, p. 2).

COVID-19 leads to fear and stress on financial markets where there is an increase in volatility of prices. The COVID-19 pandemic has reduced global oil demand. Saudi Arabia began a war of oil price against Russia on 9 March 2020 and flooding markets with oil. In one day, the price of crude oil declined by $20 \%$. This puts pressure on financial markets during this day (Arezki, Fan \& Nguyen, 2020, p. 2) and (Gaffen, 2020, p. 3).

COVID-19 is a pandemic that has a lot of effects. There are political and economic impacts of coronavirus. Channels like trade and investment can tranfer the effect of coronavirus on the economies of countries, resulting in a decline in oil prices (Haruna, 2020, pp. 1-2).

The GCC states face a shock of collapse in oil prices collapse because of coronavirus spread. On 16 April 2020, Qatar reported 4,130 cases of coronavirus, Saudi Arabia 6,380, Kuwait 1,524, United Arab Emirates 5,825, Bahrain 1,700, and Oman 1,019 (Arezki, Fan \& Nguyen, 2020, p. 1).

This research explains the impact of a drop in oil prices on the economic growth of GCC states by using monthly data for (2019/2020 M1 - 2019/2020 M12), by determining the empirical and theoretical literature reviews of the impact of a drop in oil priceson economic growth, and estimating the impact of a drop in oil priceson the economic growth of GCC states by using monthly data for (2019/2020 M1 - 2019/2020 M12) using the autoregressive distributed lag (ARDL) technique in Eviews program as follows: 


\section{Research Questions}

The basic question of the research is: what are the impacts of a drop in prices of oil on the economies of GCCstates by using monthly data for (2019/2020 M1 - 2019/2020 M12)?

The following are other questions that may arise from the basic question:

1. What are the empirical and theoretical literature reviews that determine the effect of a drop in prices of oil on economic growth?

2. What is the slope of the curve of the price of oil for GCC states using monthly data for (2019/2020 M1 2019/2020 M12)?

3. What is the declivity of the curve of the economic growth of GCC states by using monthly data for (2019/2020 M1 - 2019/2020 M12)?

\section{Research Aims}

The main objective of the study is to test the impacts of a drop in prices of oil on the economies of GCC states by using monthly data for (2019/2020 M1 - 2019/2020 M12).

\section{Research Hypothesis}

The basic hypothesis of the paper is: there is a positive impact of prices of oil on economic growth in GCC states by using monthly data for (2019/2020 M1 - 2019/2020 M12).

\section{Literature Review}

The effect of a drop in oil prices on economic growth can be explained as follows:

The negative demand shock appears to be regional and global. Economic problems in the world and the global value chains distribution lower demand on goods and services in the GCC countries, especially oil. Domestic demand will decrease because of the decrease in business activities and thus decreasing travel. Also, uncertainty about the virus spread and the total demand level will lead to lower domestic consumption and investment. Decreasing oil prices of oil leads to lower demand in GCC countries where oil and gas are the vital sectors in a lot of countries. Finally, volatility of the financial market could decrease total demand (Fardella, Young \& Al-Sarihi, 2020, p. 1) and (Arezki, Fan \& Nguyen, 2020, p. 2).

Also, the breakdown of negotiations between OPEC and its allies in the first week of March decreased the prices of oil. At the end of March, the price of crude oil was 22.04 US Dollars (lower than half the price at the beginning of the month) per barrel. On 12 April 2020, OPEC started decreasing production by 9.7 million barrels each day in May and June. This leads to an expectancy of a recovery in prices of oil in the market gradualy but a price of 45 USD per barrel may not be achieved untill the end of 2022 (Baldwin \& Weder di Mauro, 2020) and (Arezki, Fan \& Nguyen, 2020, p. 2).

The decrease in prices of oil lowers the income of GCC countries obtained by multiplying the difference between consumption and production as a percentage of GDP by the prices of oil percentage point change. This would show a decrease of about $20 \%$ in real income as a percentage of GDP (Gali, 2020) and (Albulescu, 2020).

The declining trend in industrial production in Europe led to pressure on oil prices as there is an oversupply in the global markets while the United States is self-sufficient in energy. Also, lower costs and technological advances led to an oversupply in the global markets for crude. This is as a result of the new cuts approved by Russia and Saudi Arabia (Kouam \& Kingsly, 2020).

The production cost of crude oil in Saudi Arabia is 5 US Dollars per barrel on average. The selling price of 20 US Dollars per barrel of crude will have an effect on producers of oil in the United States. The average production cost for oil producers will be between 25 and 35 US Dollars in the United States. This will lead to force the US to stop production of about 2 to 3 million barrels of oil and will allow Saudi Arabia to have a higher share of world production of oil. The war of oil market dominance between Saudi Arabia and Russia will have a higher effect on the global oil industry (Ajami, 2020) and (Mzoughi \& et al, 2020).

At the end of the empirical and theoretical literature, the researcher can refer to the negative impact of a drop in prices of oil because it leads to a decrease in real income of GCC states (Bloomberg, 2020) and (Baldwin \& Weder di Mauro, 2020). 


\section{Effect of a Drop of Oil Prices on the Economic Growth of GCC States by Using Monthly Data for (2019/2020 M1 - 2019/2020 M12)}

\subsection{Method}

The rsearch uses monthly data for (2019/2020 M1 - 2019/2020 M12) for oil pricesand economic growth variables ofGCC states. The next equation represents the impact of a drop in oil priceson the growth rate of GDP of GCC states:

$$
\text { Economic growth } \left.h_{t}=f(\text { oil prices })_{t}\right)
$$

\subsection{Results}

This part explains a drop in oil prices on the growth rate of GDP of GCC states by using monthly data for (2019/2020 M1 - 2019/2020 M12) as follows:

\subsubsection{Oil Prices for GCC States}

Table 1. Oil prices for GCC states by using monthly data for (2019/2020 M1 - 2019/2020 M12)

\begin{tabular}{cc}
\hline Year & Oil prices for GCC states \\
\hline $2019 / 2020 \mathrm{M} 1$ & 54.01 \\
$2019 / 2020 \mathrm{M} 2$ & 54.56 \\
$2019 / 2020 \mathrm{M} 3$ & 55.11 \\
$2019 / 2020 \mathrm{M} 4$ & 52.63 \\
$2019 / 2020 \mathrm{M} 5$ & 55.96 \\
$2019 / 2020 \mathrm{M} 6$ & 55.39 \\
$2019 / 2020 \mathrm{M} 7$ & 62.01 \\
$2019 / 2020 \mathrm{M} 8$ & 50.7 \\
$2019 / 2020 \mathrm{M} 9$ & 46.57 \\
$2019 / 2020 \mathrm{M} 10$ & 20.65 \\
$2019 / 2020 \mathrm{M} 11$ & -38.35 \\
2019/2020M12 & 35.26
\end{tabular}

Source: Prepared by a researcher depending on Trading Economics Data

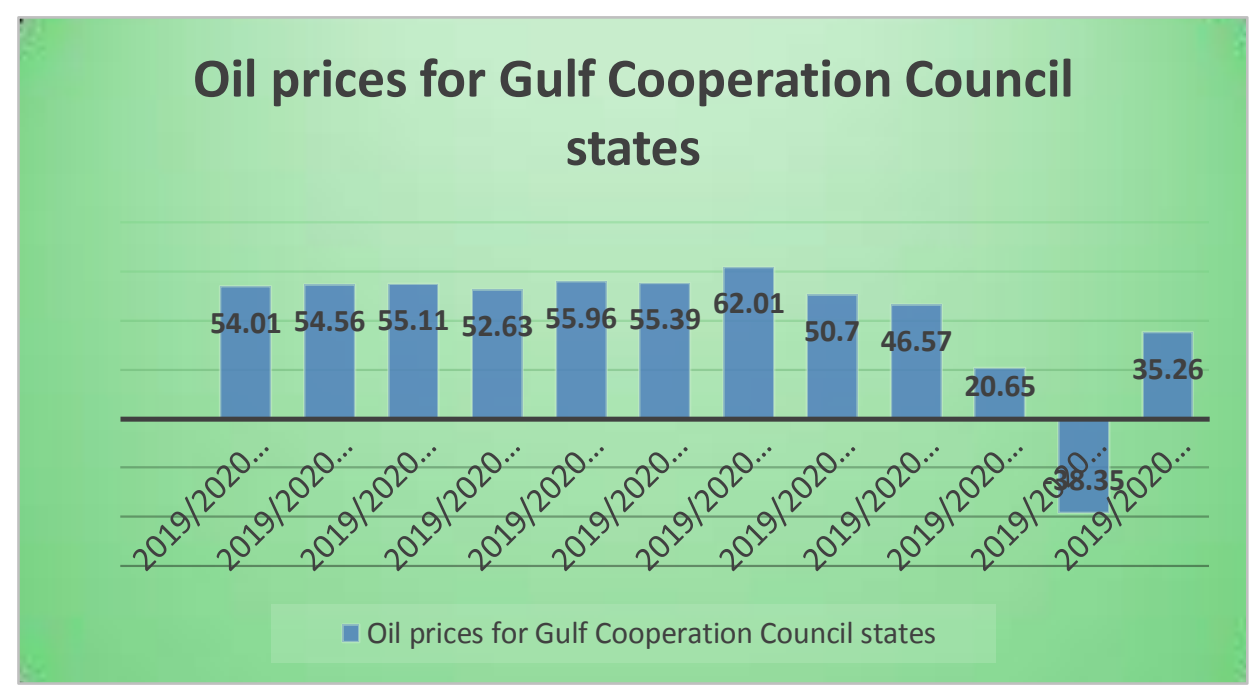

Figure 1. Oil prices for GCC states by using monthly data for (2019/2020 M1 - 2019/2020 M12)

Source: Prepared by a researcher depending on the collected data of Trading Economics 
Table 1 and Figure 1 show a fluctuation in oil prices for GCC states by using monthly data for (2019/2020 M1 2019/2020 M12). Oil price increases in the first 6 months to reach 62.01 US Dollars per barrel. After that, the price of oil decreases due to coronavirus to reach 20.65 US Dollars per barrel in 2019/2020 M10. It reaches a negative figure in 2019/2020 M11 to reach - 38.35 US Dollars per barrel.

\subsubsection{Economic Growth of GCC States}

Table 2. Economic growth of GCC states by using monthly data for (2019/2020 M1 - 2019/2020 M12)

\begin{tabular}{ccccccc}
\hline Year & $\begin{array}{c}\text { Economic } \\
\text { growth of } \\
\text { Saudi } \\
\text { Arabia }\end{array}$ & $\begin{array}{c}\text { Economic } \\
\text { growth of } \\
\text { Kuwait }\end{array}$ & $\begin{array}{c}\text { Economic } \\
\text { growth of } \\
\text { United } \\
\text { Arab } \\
\text { Emirates }\end{array}$ & $\begin{array}{c}\text { Economic } \\
\text { growth of } \\
\text { Qatar }\end{array}$ & $\begin{array}{c}\text { Economic } \\
\text { growth of } \\
\text { Bahrain }\end{array}$ & $\begin{array}{c}\text { Economic } \\
\text { growth of } \\
\text { Oman }\end{array}$ \\
\hline $2019 / 2020 \mathrm{M} 1$ & 1.7 & 1.8 & 2.2 & -2.6 & -2.5 & 0.47 \\
$2019 / 2020 \mathrm{M} 2$ & 1.5 & 1.5 & 2 & -2.3 & -1.5 & 0.52 \\
$2019 / 2020 \mathrm{M} 3$ & 1.1 & 1.1 & 1.9 & -1.9 & -0.9 & 0.67 \\
$2019 / 2020 \mathrm{M} 4$ & 0.5 & 0.1 & 1.6 & -0.9 & 3.4 & 0.9 \\
$2019 / 2020 \mathrm{M} 5$ & 0.2 & -0.2 & 1.2 & 2 & 2.5 & 0.6 \\
$2019 / 2020 \mathrm{M} 6$ & -0.6 & -0.5 & 1 & 2.5 & 1.6 & 0.5 \\
$2019 / 2020 \mathrm{M} 7$ & -0.5 & -1.1 & 0.9 & 4.7 & -0.4 & 0.3 \\
$2019 / 2020 \mathrm{M} 8$ & -0.4 & -1.5 & 0.8 & 3 & -0.7 & 0.1 \\
$2019 / 2020 \mathrm{M} 9$ & -0.6 & -1.6 & 0.9 & 1.5 & -1.2 & -0.3 \\
$2019 / 2020 \mathrm{M} 10$ & -0.7 & -1.7 & 0.7 & 0.5 & -1.4 & -1.5 \\
$2019 / 2020 \mathrm{M} 11$ & -0.2 & 2.8 & 2 & -1.4 & -1.2 & -2.84 \\
$2019 / 2020 \mathrm{M} 12$ & -0.5 & 2.5 & 1.9 & -1.2 & 0.9 & -1.9 \\
\hline
\end{tabular}

Source: Prepared by a researcher depending on Trading Economics Data

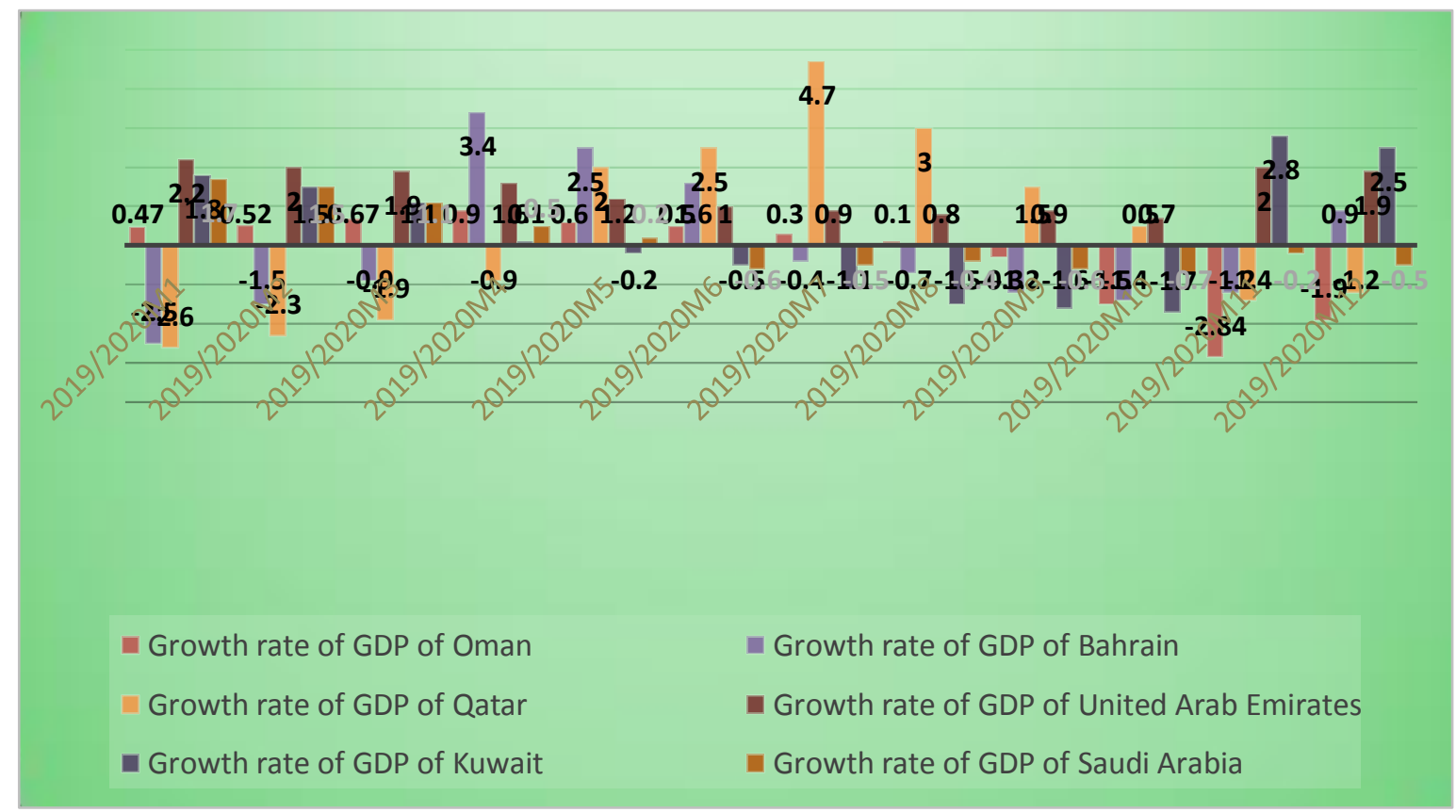

Figure 2. Economic growth of GCC states by using monthly data for (2019/2020 M1 - 2019/2020 M12)

Source: Prepared by a researcher depending on the collected data of Trading Economics 
Table 2 and Figure 2 show a fluctuation in the economic growth of GCC states by using monthly data for (2019/2020 M1 - 2019/2020 M12), but there is a decrease in it in these countries in the last months of the fiscal year 2019/2020 due to coronavirus spread.

\section{Estimation}

The following table and figure show the effect of a drop in oil prices on the economic growth of GCC states by using monthly data for (2019/2020 M1 -2019/2020 M12) as follows:

Table 3. Oil prices and Economic growth of GCC states by using monthly data for (2019/2020 M1 - 2019/2020 M12)

\begin{tabular}{|c|c|c|c|c|c|c|c|}
\hline Year & $\begin{array}{c}\text { Economic } \\
\text { growth of } \\
\text { Saudi } \\
\text { Arabia }\end{array}$ & $\begin{array}{c}\text { Economic } \\
\text { growth of } \\
\text { Kuwait }\end{array}$ & $\begin{array}{c}\text { Economic } \\
\text { growth of } \\
\text { United } \\
\text { Arab } \\
\text { Emirates }\end{array}$ & $\begin{array}{c}\text { Economic } \\
\text { growth of } \\
\text { Qatar }\end{array}$ & $\begin{array}{c}\text { Economic } \\
\text { growth of } \\
\text { Bahrain }\end{array}$ & $\begin{array}{c}\text { Economic } \\
\text { growth of } \\
\text { Oman }\end{array}$ & $\begin{array}{c}\text { Oil } \\
\text { prices } \\
\text { for } \\
\text { GCC } \\
\text { states }\end{array}$ \\
\hline 2019/2020M1 & 1.7 & 1.8 & 2.2 & -2.6 & -2.5 & 0.47 & 54.01 \\
\hline 2019/2020M2 & 1.5 & 1.5 & 2 & -2.3 & -1.5 & 0.52 & 54.56 \\
\hline 2019/2020M3 & 1.1 & 1.1 & 1.9 & -1.9 & -0.9 & 0.67 & 55.11 \\
\hline 2019/2020M4 & 0.5 & 0.1 & 1.6 & -0.9 & 3.4 & 0.9 & 52.63 \\
\hline 2019/2020M5 & 0.2 & -0.2 & 1.2 & 2 & 2.5 & 0.6 & 55.96 \\
\hline 2019/2020M6 & -0.6 & -0.5 & 1 & 2.5 & 1.6 & 0.5 & 55.39 \\
\hline 2019/2020M7 & -0.5 & -1.1 & 0.9 & 4.7 & -0.4 & 0.3 & 62.01 \\
\hline 2019/2020M8 & -0.4 & -1.5 & 0.8 & 3 & -0.7 & 0.1 & 50.7 \\
\hline 2019/2020M9 & -0.6 & -1.6 & 0.9 & 1.5 & -1.2 & -0.3 & 46.57 \\
\hline 2019/2020M10 & -0.7 & -1.7 & 0.7 & 0.5 & -1.4 & -1.5 & 20.65 \\
\hline 2019/2020M11 & -0.2 & 2.8 & 2 & -1.4 & -1.2 & -2.84 & -38.35 \\
\hline 2019/2020M12 & -0.5 & 2.5 & 1.9 & -1.2 & 0.9 & -1.9 & 35.26 \\
\hline
\end{tabular}

Source: Prepared by a researcher depending on Trading Economics Data

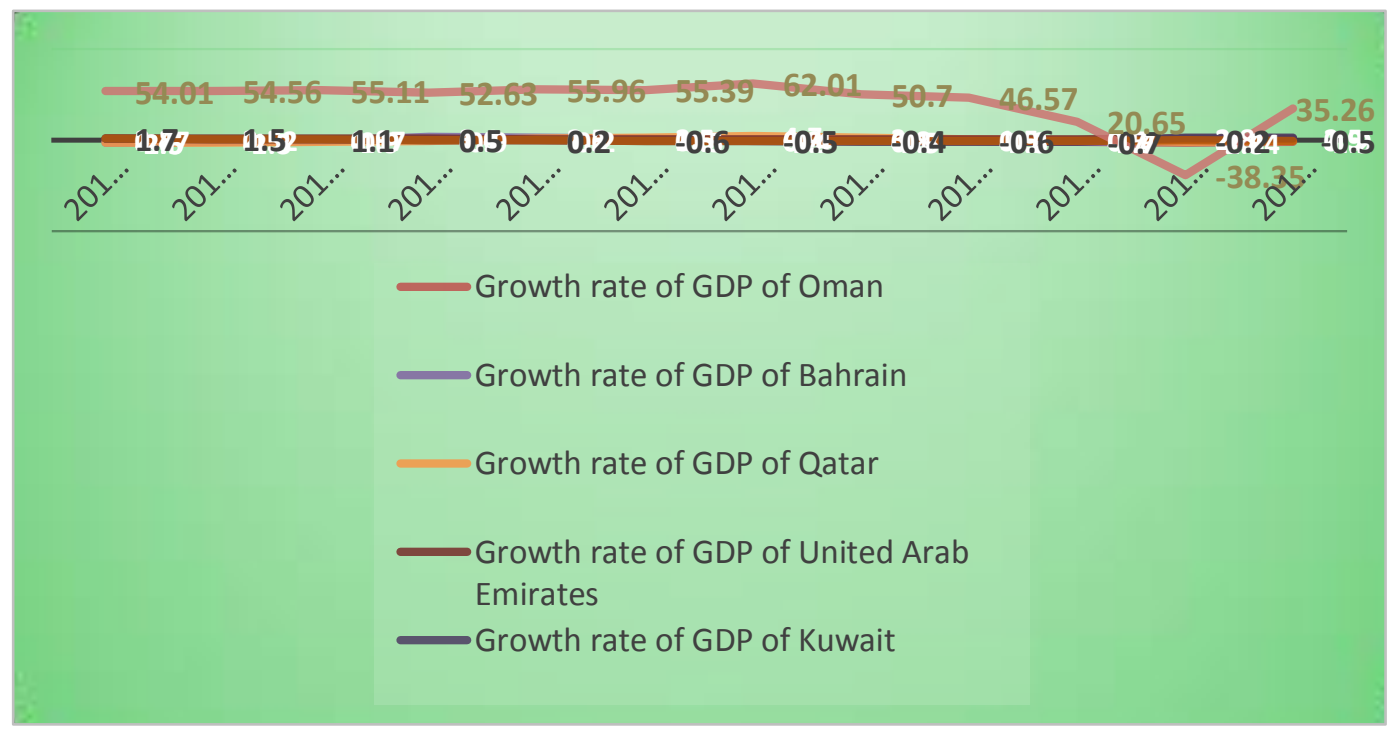

Figure 3. Oil prices and Economic growth of GCC states by using monthly data for (2019/2020 M1 - 2019/2020 M12)

Source: Prepared by a researcher depending on the collected data of Trading Economics 
Table 3 and Figure 3 show the effect of oil price on the economic growth of GCC states by using monthly data for (2019/2020 M1 - 2019/2020 M12). The above table and figure refer to a negative effect of a drop in oil prices on the economic growth of GCC states; as when the drop in oil price increases, economic growth lowers.

To verify this effect, the researcher used the autoregressive distributed lag (ARDL) technique to test the effect of a drop in oil price on the economic growth of GCC states by using monthly data for (2019/2020 M1 - 2019/2020 M12)as follows:

Method: ARDL

Date: 06/25/20 Time: 13:12

Sample (adjusted): 2019M02 2019M12

Included observations: 11 after adjustments

Dependent lags: 1 (Fixed)

Dynamic regressors (0 lag, fixed): GRBA GRKU GROM GRQA GRSA

GRUAE

Fixed regressors: C

\begin{tabular}{lllll} 
Prob.* & t-Statistic & Std. Error & Coefficient & Variable \\
\hline 0.0006 & -14.95918 & 0.057153 & -0.854962 & PRICE(-1) \\
0.8720 & -0.175324 & 3.580228 & -0.627699 & GRBA \\
0.0125 & -5.392943 & 0.670877 & -3.618001 & GRKU \\
0.1799 & 1.741678 & 4.171624 & 7.265628 & GROM \\
0.1099 & -2.250212 & 12.75671 & -28.70530 & GRQA \\
0.0007 & 14.26229 & 2.207706 & 31.48696 & GRSA \\
0.9833 & -0.022692 & 1.058869 & -0.024028 & GRUAE \\
0.0058 & 7.072421 & 17.72230 & 125.3396 & C \\
\hline 40.95364 & \multicolumn{2}{c}{ Mean dependent var } & 0.997933 & R-squared \\
28.73865 & S.D. dependent var & 0.993110 & Adjusted R-squared \\
4.731917 & Akaike info criterion & 2.385452 & S.E. of regression \\
5.021295 & Schwarz criterion & 17.07115 & Sum squared resid \\
4.549504 & Hannan-Quinn criter. & -18.02554 & Log likelihood \\
2.626335 & Durbin-Watson stat & 206.9163 & F-statistic \\
& & 0.000509 & Prob(F-statistic) \\
\hline
\end{tabular}

The above table refers to negative and significant effects of a drop in oil price on the economic growth of Kuwait and Qatar, but insignificant effects of a drop in oil price on the economic growth of Bahrain, Oman and the United Arab Emirates and a positive and significant effect of a drop of oil price on the economic growth of Saudi Arabia by using monthly data for (2019/2020 M1 - 2019/2020 M12) at a level of significance of 5\%.

\section{Conclusion and Recommendations}

The research estimates a drop in oil price effect on economic growth in the empirical and theoretical literature reviews, and a drop in oil price effect on the economic growth of GCC states by using the autoregressive distributed lag (ARDL) technique by using monthly data for (2019/2020 M1 - 2019/2020 M12). This research reached negative and significant effects of oil price on the economic growth of Kuwait and Qatar, but insignificant effects of oil price on the economic growth of Bahrain, Oman and the United Arab Emirates and a positive and significant effect of oil price on the economic growth of Saudi Arabia by using monthly data for (2019/2020 M1 - 2019/2020 M12) at a significance level 5\%. To enhance economic growth, this paper recommends that the GCC states should improve on their economies via other sectors other than oil as depending on oil only is not good enough. 


\section{References}

Ajami, R. (2020). Globalization, the Challenge of COVID-19 and Oil Price Uncertainty. Journal of Asia-Pacific Business, 21(2), 77-79. https://doi.org/10.1080/10599231.2020.1745046

Albulescu, C. (2020, March). Coronavirus and Oil Price Crash: A note. Polytechnic University of Timisoara, 1-13. https://doi.org/10.2139/ssrn.3553452

Albulescu, C. (2020, March). DO COVID-19 and Crude Oil Prices Drive the US Economic Policy Uncertainty?. Polytechnic University of Timisoara, 1-7. https://doi.org/10.2139/ssrn.3555192

Arezki, R., Fan, R., \& Nguyen, H. (2020, April). COVID-19 and Oil Price Collapse: Coping with a Dual Shock in the Gulf Cooperation Council. Economic Research Forum, Policy Brief No. 52, 1-7. https://erf.org.eg/wp-content/uploads/2020/04/PB-52_Rabah_version3.pdf

Baldwin, R., \& Weder di Mauro, B. (2020). Mitigating the COVID Economic Crisis: Act Fast and Do Whatever It Takes. VoxEU. Retrieved from https://voxeu.org/content/mitigating-covid-economic-crisis-act-fast-and-do-whatever-it-takes

Bloomberg. (2020, April). Abu Dhabi Raises \$7 Billion to Bolster Finances. Retrieved from https://www.bloomberg.com/news/articles/2020-04-08/abu-dhabifollows-qatar-with-bond-as-oil-states-bolster-fi nances

Fardella, E., Young, K., \& Al-Sarihi, A. S. (2020, May). KFCRIS Report on the Regional and International Impact of Coronavirus. King Faisal Center for Research and Islamic Studies, No. 5. Retrieved from https://www.kfcris.com/pdf/353d7a6032f07a6398a8eee6bc16082e5eaffee7816b7.pdf

Gaffen, D. (2020, April). What the Future May Hold for Oil Amidst COVID-19?. World Economic Forum. Retrieved from

https://www.weforum.org/agenda/2020/04/the-week-when-oil-cost-minus-38-a-barrel-what-it-means-whats-co ming-next

Gali, J. (2020). Helicopter Money: The Time Is Now. VoxEU. Retrieved from https://voxeu.org/article/helicopter-money-time-now

Haruna, I. (2020, March). Economic Impact of Covid-19 on Ghana: What are the Channels? University for Development Studies, Wa Campus, 1-6. Retrieved from https://www.researchgate.net/publication/340117125_ECONOMIC_IMPACT_OF_COVID-19_ON_GHANA_ WHAT_ARE_THE_CHANNELS

Kouam, H. \& Kingsly, K. (2020, January). COVID-1 and Oil Prices. SSRN Electronic Journal, 1-14. https://doi.org/10.2139/ssrn.3555880

Mzoughi, H., et al.. (2020, April). The effects of COVID-19 pandemic on oil prices, CO2 emissions and the stock market: Evidence from a VAR model. SSRN Electronic Journal, 1-9. https://doi.org/10.2139/ssrn.3587906

\section{Copyrights}

Copyright for this article is retained by the author(s), with first publication rights granted to the journal.

This is an open-access article distributed under the terms and conditions of the Creative Commons Attribution license (http://creativecommons.org/licenses/by/4.0/). 